\title{
Developing the common law crime of murder in relation to physician-assisted suicide and physician-assisted euthanasia: Revisiting the missteps of Stransham-Ford $v$ Minister of Justice and Correctional Services 2015 (4) SA 50 (G)
}

\author{
Ntokozo Mnyandu \\ LLB LLM (UKZN) \\ Lecturer, School of Law, University of KwaZulu-Natal
}

\begin{abstract}
SUMMARY
The paper reflects on the court's attempt in Stransham-Ford $v$ Minister of Justice and Correctional Services to develop the common law in relation to physician assisted suicide and physician assisted euthanasia. It does so by first considering whether lawful avenues which may potentially curtail life bring meaningful relief for persons facing terminal illness and intractable suffering. The paper demonstrates that these avenues do not provide an assurance that the dying process will be quick, painless and dignified. In some instances, these avenues may even lead to protracted suffering.

It is these considerations that prompted Stransham-Ford to request the High Court to develop the common law. In turn, the paper considers the missteps of the court's attempt to develop the common law. It does so by considering whether the court followed a proper remedy when it held that the prohibition on physician assisted euthanasia and physician assisted suicide requires development to give effect to Stransham-Ford's constitutional right to dignity and freedom of bodily and psychological integrity. Turning to the thesis of the research, the paper argues that the court adopted a remedy that was inappropriate for developing the common law. The court erroneously used a remedy that is reserved for invalid statutory provisions. In doing so, the court overlooked the demands of section 39(2) read with section 173 of the Constitution. Remedies that are appropriate in matters dealing with breaches of the Constitution by common law principles are referred to and discussed. Furthermore, the research considers which of the available common law remedies would have been constitutionally sound in the circumstances of the case.
\end{abstract}

\section{Introduction}

A physician who assists by way of giving a patient a lethal prescription, which the patient may use to bring about his death, is commonly referred to as physician-assisted suicide. If the physician is called upon to assist with administering the lethal prescription, he or she engages in physician-assisted euthanasia. Despite Stransham-Ford's attempt at challenging the absolute prohibition of physician-assisted euthanasia and

How to cite: Mnyandu 'Developing the common law crime of murder in relation to physician-assisted suicide and physician-assisted euthanasia: Revisiting the missteps of Stransham-Ford v Minister of Justice and Correctional Services 2015 (4) SA 50 (G)'2021 De Jure Law Journal 249- 264 http://dx.doi.org/10.17159/2225-7160/2021/v54a15 
physician-assisted suicide, they remain unlawful. The position with respect to physician-assisted euthanasia can be gleaned from the cases of $S$ Hartmann ${ }^{1}$ and $R v$ Peverett. ${ }^{2}$ In the former, the court held that it constitutes the crime of murder to hasten the death of a human being even if they were due to die of terminal illness, and in the latter, it was held that consent is not a defence to criminal responsibility. In instances of physician-assisted suicide it has been held that a person who provides the necessary means for an intended suicide will be guilty of an offence. ${ }^{3}$

A court confronted with a challenge to the absolute prohibition of physician-assisted euthanasia (PAE) and physician-assisted suicide (PAS) would have to consider how the principles of criminal law should be applied and adopted to the present day. In doing so, the court would also have to heed the requirement of section 39(2) of the Constitution, ${ }^{4}$ that is whether the law relating to PAE and PAS requires development in order to promote the spirit, purport and objects of the Bill of Rights. Stransham-Ford had approached the High Court for an order declaring that the law on PAE and PAS be developed, so as to give effect to his constitutional rights.

The research reflects on the court's attempt to develop the common law. It does so by considering whether the court followed a proper remedy when it held that the prohibition on PAE and PAS requires development to give effect to Stransham-Ford's constitutional right to dignity and his right to bodily and psychological integrity. ${ }^{5}$ Turning to the thesis of the research, the paper argues that the High Court in StranshamFord $v$ Minister of Justice and Correctional Services ${ }^{6}$ adopted a remedy that was inappropriate for developing the common law. The court erroneously used a remedy that is reserved for impugned statutory provisions. Remedies that are appropriate in matters dealing with breaches of the Constitution by common law principles are referred to and discussed. Furthermore, the research considers which of the available common law remedies would have been constitutionally sound in the circumstances of the case.

It bears mentioning that although the decision in Stransham-Ford was criticised on several grounds and subsequently overturned on appeal, the Supreme Court of Appeal did not fully consider the missteps flowing from the manner in which the High Court had sought to develop the common law.

$S v$ Hartmann 19753 SA 523 (C) 534E-F.

$R v$ Peverett 1940 AD 213.

3 Ex Parte Die Minister van Justisie: In Re Sv Grotjohn 19702 SA 355 (A) 364B$\mathrm{H}$.

4 S 39(2) of the Constitution of the Republic of South Africa, 1996.

5 S 10 and s 12(2) of the Constitution of the Republic of South Africa, 1996.

6 Stransham-Ford $v$ Minister of Justice and Correctional Development 20154 SA $50(\mathrm{GP})$. 


\section{Background}

A painful and protracted death makes it difficult to prescribe what ought to be done and endured and it is even more challenging to abide by the decision. ${ }^{7}$ Should we struggle on and rage against the dying light as suggested by Dylan Thomas, ${ }^{8}$ or follow Socrates by letting go and accepting death as the greatest of all human blessings?

Advances in the ability of medical technology to prolong life has further complicated these choices. Although welcomed, in some instances prolonging life can lead to the process of dying being painful, burdensome, and protracted. Social commentators, politicians and philosophers have debated over the years on how we should solve this impasse, ${ }^{10}$ which for some is a lived and frightening experience. ${ }^{11}$

Patients who are suffering from an intractable illness may wish to shorten their life as a form of escape. ${ }^{12}$ The pain is so unbearable that it leads them to plead to die or to be killed. ${ }^{13}$ In South Africa, there are very few avenues open to persons who face terminal illness of this kind. As an option they may lawfully bring about death by refusing life-prolonging interventions. The refusal of treatment is constitutionally protected, because it falls in the protected realm of the right to bodily integrity. ${ }^{14}$ Furthermore, a physician who accedes to this request would not be committing an offence, as anything contrary to the patient's wishes may constitute an assault. ${ }^{15}$ Refusal of treatment merely allows the disease to progress naturally, and if death results it would be primarily because of

$7 \quad$ Aristotle Nicomachean Ethics (2001) 24. An example of this can be sourced from the High Court case of Stransham-Ford. Days after approaching the High Court for an order that would allow him to be killed lawfully, Stransham-Ford inquired as to whether he could change his mind about the need for assisted suicide. It therefore seems that he found it difficult to abide by the decision to seek assisted death.

8 Dylan Thomas $1914-1953$ Do not go gentle into that good night.

9 As quoted in Plato's Apology 40e.

10 Jacobs "Legalising physician-assisted suicide in South Africa: Should it even be considered?" 2018 S Afri J Bioethics Law 67.

11 In Dworkin Life's Dominion: An Argument About Abortion, Euthanasia and Individual Freedom (1993) 179, Dworkin states that many rational people, the world over, plead to be allowed to die. Some of these persons, like Stransham-Ford, are in great pain. In a graphic explanation, he recounts the experience of Lillian Boyes, who was an elderly woman dying from an extreme form of rheumatoid arthritis. He tells of her experience of pain as being insensible to potent painkillers - to the extent that she would scream even when touched by her son.

12 Intractable pain is a relentless and debilitating pain which is not curable, and which causes a patient to be bedridden and which brings about death.

13 Dworkin 179.

14 Castell v De Greef 19944408 (C) 409A-B.

15 Carstens and Pearmain Foundational Principles of South African Medical Law (2007) 681. Here Carstens quotes Van Oosten who writes: “... where a medical intervention has been performed without the patients informed consent, but with due care and skill and has proved to be beneficial to the patient's health: Here the appropriate action would be assault or inuria." 
the underlying disease and not the result of self-inflicted injury. ${ }^{16}$ However, the refusal of treatment holds little respite for persons who wish to end their suffering by bringing a quick and painless end to their lives. A lawful alternative which is at the disposal of those close to death is palliative treatment or the withholding or withdrawal of treatment.

McQuoid-Mason points out that a physician or a curator personae would not be liable for murder where death is induced by the withholding or withdrawing of treatment in instances where further treatment would amount to a fruitless attempt to save life, or where the benefits are outweighed by the risks. ${ }^{17}$ The position stands, though it is arguable that the physician or the curator personae intentionally caused the death of another person. The real reason why no liability is imputed, is because the intentional causation of harm is lawful. ${ }^{18}$ Essentially, the court, in light of public and legal policy consideration, regards the cessation of treatment and the consequence harm as being reasonable. ${ }^{19}$ The court in Clarke $v$ Hurst, ${ }^{20}$ clarified the determination of lawfulness in relation to the cessation or withdrawal of treatment:

“... the decision whether the discontinuance of the artificial nutrition[ing] of the patient and his resultant death would wrongful, depends on whether, judged by the legal convictions of our society, it boni mores, it would be reasonable to discontinue the artificial nutrition[ing] of the patient."21

It is generally accepted that a patient's life will be curtailed where life sustaining treatment is refused or the same is withheld or withdrawn. Furthermore, and perhaps more meaningful to such patients, is that if treatment is refused, withheld or withdrawn, it saves them from unwanted consequences of life-prolonging medical interventions that have the potential to lower quality of life. ${ }^{22}$ Patients who request PAE and PAS often do so in order to escape intractable suffering. One such patient was Stransham-Ford, who had indicated that there is no dignity in dying at hospital while being dulled with opioids. It may appear that refusing, withholding and withdrawing treatment has the effect of improving the quality of life at the moment of death. However, proponents of PAE and PAS would argue that it does nothing to relieve the indignity of being

16 Re Conroy 486 A 2d 1209 (NJSC 1985) at 1224.

17 McQuoid-Mason "Withholding or withdrawing treatment and palliative treatment hastening death: The real reason why doctors are not held legally liable for murder" 2014 SAMJ 103.

18 McQuoid-Mason 103.

19 Clarke $v$ Hurst NO 19924 SA 630 (D) 653A-B. It trite that it is lawful for a mentally competent patient to refuse medical treatment, even if it will cause their death. However, it in cases where a patient cannot consent and a decision must be taken on his behalf on whether the decision to cease or withhold treatment is lawful will be judged according to the circumstances of the case as well as policy considerations, see Clarke v Hurst NO 19924 SA 630 (D) $651 \mathrm{E}-\mathrm{F}$

20 Clarke $v$ Hurst NO supra.

21 Clarke $v$ Hurst NO supra, 653A-B.

22 Reichlin "On the ethics of withholding and withdrawing medical treatment" 2014 Multidisciplinary Respiratory Medicine 39. 
dependent on others to attend to every detail of their daily lives and the incurable pain associated with terminal illness. ${ }^{23}$

However, incurable pain and the quality of life may be improved by palliative care. The Supreme Court of Appeal in the case of StranshamFord had indicated that in recent times there have been considerable advances in palliative care - to the extent that the impact of palliative care had surpassed Stransham-Ford's expectations and predictions of a frightening and undignified death. ${ }^{24}$ His symptoms had been managed effectively enough for him to be able to die at home, surrounded by friends and family. It is argued elsewhere and echoed here that while the debate on the legalisation of PAE and PAS continues, we ought to focus on making certain that palliative care services are readily available for those who need them. ${ }^{25}$ Palliative care is lawful - even though it could potentially hasten death. ${ }^{26}$ It is lawful because the causing of harm is reasonable where:

“... the purpose of medicine, the restoration of health, can no longer be achieved, there is still much for a doctor to do, and he is entitled to do all that is proper and necessary to relieve pain and suffering, even if measures he takes may incidentally shorten life." 27

A further lawful alternative for persons who seek to escape intractable illness is death by suicide. Death by suicide is the act of intentionally bringing about one's own death. Such an act is not punishable for it places the responsible person beyond the reach of the law. However, it is generally understood that legal and societal norms neither support nor favour suicide. ${ }^{28}$ The position is unlikely to change because suicide often occurs outside a clinical setting, the consequence of which is that it could severely impair bodily functions and it might not have the desired effect of bringing about a hasty and painless death.

In an endeavour to make the dying process as bearable and painless as possible, those making a decision at the end of their lives have often requested that they be allowed to solicit the assistance of a physician in committing suicide. A physician who assists by way of giving a patient a lethal prescription, which the patient may use to bring about his death,

23 Behrens "Assisted dying: Why the argument from Sufficient Palliation fails" 2017 South African Journal of Philosophy 191.

24 Minister of Justice and Correctional Services $v$ Estate Stransham-Ford 20173 SA 152 (SCA) 188I-189A.

25 Mnyandu "Exploring the concept of Ubuntu in relation to dying with dignity in palliative and hospice care" 2018 Obiter 398.

26 There is a general understanding to the contrary that states that advances in medical knowledge and skill enable physicians to improve the quality of life without shortening it. Gwyther argues that "there is no evidence that the use of opioids or sedatives in palliative care" has the consequence of a double effect; see Gwyther "Palliative care: Preventing misconceptions" 2014 SAMJ 261.

27 McQuoid-Mason 103; R v Adams 1957 Crim LR 365.

28 Labuschagne quoted in Kok "Delictual liability in case of suicide" 2001 Stell LR 161 . 
is commonly referred to as physician-assisted suicide. If the physician is called upon to assist with administering the lethal prescription, he or she engages in physician-assisted euthanasia. Stransham-Ford had requested PAE, and, in the alternative, PAS. As stated earlier, a person, and this includes a physician who administers a lethal prescription to a patient at the latter's request, "commits the crime of murder". 29 As to whether a person or physician who assists another person to commit suicide is guilty of an offence, will be determined in accordance with the principles of criminal law. In a case dealing with assisted suicide, the court in Ex Parte Die Minister van Justisie: In Re S v Grotjohn clarified that:

"In connection with encouragement and help corresponding considerations apply. Both the encourager and the helper could, in the light of circumstances of the particular case, be found guilty of murder or attempted murder."30

It is for this reason that Stransham-Ford approached the High Court requesting that the law relating to the absolute prohibition of PAS and PAE be developed so as to protect and give effect to his right to dignity and freedom of bodily and psychological integrity. A brief history of the circumstances of the case follows. and thereafter an interrogation of the manner in which the court attempted to develop the common law.

\section{Stransham-Ford $v$ Minister of Justice and Correctional Services ${ }^{31}$}

Stransham-Ford was diagnosed with prostate cancer on 19 February 2013. The cancer became progressive and by 13 March 2015 it had spread to his lymph glands and would eventually reach stage four by the time of his death. On 17 April 2015, Stransham-Ford approached the High Court for an order that would declare that the common law crime of murder in the context of PAE and PAS was unjustly limiting his constitutional right to dignity and his right to bodily and psychological integrity. In effect, he construed these rights as extending to the right to die - that is the right to control the timing and the manner of one's death. 32

In deciding in his favour, the High Court referred to Carter $v$ Attorney General of Canada ${ }^{33}$ which had previously explained how one's rights to dignity and to bodily integrity can be infringed by a prohibition on assisted suicide and assisted euthanasia:

29 Minister of Justice and Correctional Services $v$ Estate Stransham-Ford supra, $171 \mathrm{E}$.

30 Ex Parte Die Minister van Justisie: In Re S v Grotjohn supra, 365F-G.

31 Stransham-Ford $v$ Minister of Justice and Correctional Services and Others 20154 SA 50 (GP)

32 Quinot "The right to die in American and South African constitutional Law" 2014 CILSA 140.

33 Carter v Attorney General of Canada [2015] 1 SCR 331. 
"an individual's response to a grievous and irremediable medical condition is a matter critical to their dignity and autonomy. The law allows people in this situation to request palliative sedation, refuse artificial nutrition and hydration, or request the removal of life sustaining medical equipment, but denies them the right to request their physician's assistance in dying. This interferes with their ability to make decisions concerning their bodily integrity and medical care and thus trenches on liberty. And ...it impinges on their security of person [as it leaves them to endure intolerable suffering]."34

The court in Carter concluded that the prohibition on assisted suicide and euthanasia violated the right to die because it imposed unnecessary suffering on affected individuals. It explained further that it caused them to be deprived of the ability to determine what to do with their bodies and how their bodies are treated. ${ }^{35}$ The High Court in Stransham-Ford adopted this reasoning and proposed to develop the common law so as to remedy the violation of rights. ${ }^{36}$ However, the manner in which it does this is suspect, and thus the approach is critically analysed. The paper argues that the High Court in pronouncing that the prohibition on assisted suicide and assisted euthanasia is unconstitutional used remedial powers that are only available when dealing with impugned legislative provisions. The court ought to have used remedial powers that are set aside for common law principles. As pointed out by Currie and De Waal:

“... legislation is approached by first interpreting it with the Constitution in mind, prior to any direct application of the Constitution (and any finding of unconstitutionality). In case of the common law, the approach is similar but not identical, the difference lying in the remedial powers of the court."37

It must be mentioned that although the precedent set by the High Court was overturned on appeal in Minister of Justice and Correctional Services $v$ Estate Stransham-Ford, ${ }^{38}$ the reasons for rejecting it do not deal with the remedial powers of the court in so far as impugned law is concerned. It is thus necessary to reflect on this and to provide clarity on the dual role of section 39(2) of the Constitution.

\section{Understanding section 39(2) of the Constitution}

\section{Interpreting legislation}

Section 39(2) provides for two things. First, it sets out the general principles of statutory interpretation. Courts must interpret the statute

34 Carter $v$ Attorney General of Canada supra.

35 Stransham-Ford $v$ Minister of Justice and Correctional Services and Others supra,66I-J.

36 Stransham-Ford $v$ Minister of Justice and Correctional Services and Others supra, 70C-D.

37 Currie and De Waal Bill of Rights Handbook (2013) Chapter 3-60.

38 Minister of Justice and Correctional Services v Estate Stransham-Ford supra. 
through the lens of the spirit, object and purport of the Bill of Rights. ${ }^{39}$ This process is carried out when there is an alleged infringement of rights in the Bill of Rights by a provision of a statute. The court will have to engage in a "threshold analysis," the process of which involves examining:

“(a) the content and scope of the relevant protected right(s) and (b) the meaning and effect of the impugned enactment to see whether there is any limitation of (a) by (b). Subsection (1) and (2) of section 39 gives guidance as to the interpretation of both the right and enactment, essentially requiring them to be interpreted so as to promote the value system of an open and democratic society based on human dignity, equality and freedom. If upon such analysis no limitation is found that is the end of the matter ..."

If a limitation does exist, the court will then have to engage in a limitation exercise which requires:

“... a weighing-up of the nature and importance of the rights(s) that are limited together with the extent of the limitation as against the importance and purpose of the limiting enactment." 41

If, notwithstanding the process, the provision is found to be constitutionally invalid, a court may, under section 172(1)(b) of the Constitution employ a number of corrective techniques. Such techniques include reading words into or severing (notional and actual) them from the statute. This is done in order to bring the provision within acceptable constitutional standards. Where a provision cannot be saved, the court may declare it unconstitutional and invalid, leaving it to the legislature to give effect to the concerned rights. It is left to the legislature to deal with it because "the responsibility and power to address the consequences of the declaration of invalidly resides, not with the courts, but pre-eminently with the legislative authority." 42 But with respect to the common law, the approach is different, as it is the law of the courts and not the legislature.

The court in Carter took a similar approach, wherein it declared that:

“... s 241 (b) and s 14 of the Criminal Code are void insofar as they prohibit physician-assisted death for a competent adult person who (1) clearly consents to the termination of life; and (2) has a grievous and irremediable medical condition (including an illness, disease or disability) that causes enduring suffering that is intolerable to the individual in the circumstances of his or her condition." 43

Essentially, the court remedied the defect in the statute by way of notional severance of the impugned provision. Notional severance is a remedy that is used to invalidate the application of a statutory provision

39 Maswazi "The doctrine of precedent and the values of s39(2) of the Constitution" 2017 De Rebus April 28.

40 Ex Parte Minister of Safety and Security: in Re Sv Walters 20024 SA 613 (CC) 631 A-B.

41 Ex Parte Minister of Safety and Security: in Re Sv Walters supra, 631 B-C.

42 Sv Thebus 20036 SA 505 (CC) 526D.

43 Carter $v$ Attorney General of Canada supra, par 127. 
to a particular matter. ${ }^{44}$ The device allows for certain parts of provisions to be left intact, while removing the offending parts. ${ }^{45}$ Furthermore, the offending section is given particular meaning in the sense that the court instructs those who apply the section to apply it to certain cases only or in certain circumstances. In the case of Carter the court rendered the application of the Criminal Code invalid, only in so far as it prohibits physician-assisted suicide for terminally ill patients. Regrettably, it seems as though the High Court in Stransham-Ford followed the same approach, it held:

"the common law crimes of murder or culpable homicide in the context of assisted suicide by medical practitioners, insofar as they provide for an absolute prohibition, unjustifiably limit the Applicant's constitutional rights to human dignity, (S. 10) and freedom to bodily integrity (S. 12 (2) (b), read with S. 1 and 7), and to that extent are declared to be overbroad and in conflict with the said provisions of the Bill of Rights."

The approach of the court is unfortunate, because the court was faced with common law principles relating to the crime of murder. As stated earlier, a court will use the device of severance only in cases that involve impugned legislative provisions. Gevers et al explain the remedy available in such cases, by stating that:

"Invalidating legislation can have drastic consequences. Courts use various techniques to limit the drastic consequences of orders of invalidity, including suspending an order of invalidity to give parliament a chance to remedy the defect, severing the bad parts of a provision from the good without invalidating an entire section and reading words into the statute to render it constitutionally valid." 46

It is argued that a different approach is required when a court deals with a constitutional challenge to a rule of common law. ${ }^{47}$ In essence, the development of the common law must take place within its own paradigm. ${ }^{48}$

\section{Developing the common law}

The second aspect of section 39(2) is that it sets out the guidelines for developing the common law. There are two instances where a common law rule may be developed:

"The first would be when a rule of the common law is inconsistent with a constitutional provision. Repugnancy of this kind would compel an adaptation of the common law to resolve the inconsistency. The second possibility arises even when a rule of the common law is not inconsistent

44 Rautenbach "Introduction to the Bill of Rights" in Bill of Rights Compendium (Last updated 2018) 1 A98.

45 Gevers, Govender, De Vos et al South African Constitutional Law in Context (2014) 502 .

46 Gevers, Govender, De Vos 522.

47 Sv Thebus supra, 526D-E.

48 Carmichele $v$ Minister of Safety and Security 20014 SA 938 (CC) 962B. 
with a specific constitutional provision but may fall short of its spirit, purport and objects. Then, the common law must be adapted so that it grows in harmony with the 'objective normative value system' found in the Constitution." 49

Dersso explains that the power to develop the common law is peremptory when the rule is inconsistent with specific provision(s) of the Constitution and that in the second instance, the common law must be developed incrementally and on a case-to-case basis. ${ }^{50}$ To this end, Stransham-Ford argued that the prohibition on assisted suicide does not accord with specific constitutional provisions, namely his right to dignity and freedom and security of the person, and therefore it requires development in terms of section 39(2). It would have been favourable to argue that the criminal prohibition of assisted suicide falls short of the spirit, purport and objects of the Constitution, as invariably criminal prohibition of conduct will be in conflict with rights such as dignity and freedoms. In doing so, one can argue that the criminal prohibition of physician-assisted suicide does not accord with changes in the social, moral and economic fabric of society, which are based on human dignity and the advancement of human rights and freedoms.

Section 39(2) provides that when developing the common law the court must promote the spirit, purport and object of the Bill of Rights. The phase "spirit, purport and objects of the Bill of Rights" has no finite meaning, but it is accepted that it is broad enough to include, inter alia, normative standards, values and ethos underlying the Constitution. 51 Just as in the case of dealing with a constitutional challenge to legislation, the court in dealing with a challenge to the common law will engage in a threshold analysis that is to determine whether the common law rule limits an entrenched right. Thereafter, a limitation exercise will follow to determine whether the limitation is justifiable in an open and democratic society. If the rule is found not to be justifiable, it will be developed so that it reflects the changing social, moral and economic makeup of society.

Common law principles that are constitutionally invalid must be developed within the paradigm of the common law and this is achieved by introducing a new rule or significantly changing an existing rule or adjusting the way in which an existing common law rule is applied. ${ }^{52}$ This position was clarified in $K v$ Minister of Safety and Security, ${ }^{53}$ where the court stated that:

"It is necessary to consider the difficult question of what constitutes 'development' of the common law for purposes of s 39(2) ... From time to

49 Sv Thebus supra, 526D-E.

50 Dersso "The Role of Courts in the development of the common law under S 39(2): Mayisa v Director of Public Prosecutions Pretoria (The State and Another CCT Case 54/06 (10 May 2007)" 2007 South African Journal on Human Rights 384.

51 Moosa "Understanding the "Spirit, Purport and Objects" of South Africa's Bill of Rights” 2017 J Forensic Leg Investig Scie 7. 
time, a common-law rule is changed altogether, or a new rule is introduced ... More commonly, however, courts decide cases within the framework of an existing rule." 54

The High Court in the Stransham-Ford case had determined that the criminal prohibition of assisted suicide does not accord with StranshamFord's rights. ${ }^{55}$ However, having engaged in a threshold analysis, the court did not engage in a limitation exercise. ${ }^{56}$ Instead, having found that there is a limitation of Stransham-Ford rights, the court sought to develop the common law. This represents another misstep in the attempted development of the common law by the North Gauteng High Court.

\section{Introducing a new rule of law}

Where the common law is concerned, a court may make an order that goes beyond the finding of invalidity to developing a new legal rule. O'Regan J pointed out in the case of $K$ that the common law is clearly developed when a new rule is introduced. ${ }^{57}$ A court will do this to give effect to the right infringed, particularly in instances where there are no rules giving effect to the right. In $S v$ Bogaards ${ }^{58}$ the court introduced a new rule in order to remedy a lacuna in common law which had resulted in an infringement of the right to a fair trial. The lacuna in common law had been that there was no requirement for an appeal court to give an accused person notice where that court, mero motu, is considering an increased sentence on appeal. ${ }^{59}$ The court developed the common law by introducing a rule that an appeal court cannot increase one's sentence without providing an accused with an opportunity to make a submission. In doing so, Kampepe J said:

"When developing the common law, a court needs first to ascertain that the right relied upon is applicable to the law or conduct that has given rise to the dispute. The court must determine whether the common law is deficient in failing adequately to protect the right. If there is no legislation or common law giving effect to the right, a court is enjoined to develop the common law in order to do so." 60

52 Brand "The role of good faith, equity and fairness in the South African Law of Contract: The influence of the common law and the Constitution" 2009 South African Law Journal 72; Mupangavanhu "Yet another Missed Opportunity to Develop the Common Law of Contract? An Analysis of Everfresh Market Virginia Pty v Shoprite Checkers (Pty) Ltd [2011] ZACC 30" 2013 Speculum Juris 153.

$53 K v$ Minister of Safety and Security 20056 SA 419 (CC).

$54 K v$ Minister of Safety and Security supra, (CC) 429B-C

55 Stransham-Ford $v$ Minister of Justice and Correctional Services 20154 SA 50 (GP) $70 \mathrm{G}$.

56 S 36 of the Constitution of the Republic of South Africa, 1996.

57 K v Minister of Safety and Security supra, 429B-C.

58 S v Bogaards 20131 SACR 1 (CC).

$59 S v$ Bogaards supra, 24D-E.

$60 S v$ Bogaards supra, 16G. 
Similarly, in $H v$ Fetal Assessment Centre, ${ }^{61}$ the court had to determine whether "wrongful life" claims should be recognised in South Africa. "Wrongful life" refers to a claim by a child against the doctor based on his failure to adequately inform the child's mother of the risk of the child being born with a disability. ${ }^{62}$ The child alleges that, but for doctor's negligence, it would not have been born to experience pain and suffering attributed to the disability. ${ }^{63}$ The Constitutional Court held that the development of the common law at stake here is of the kind where a new rule is introduced and that it was in favour of allowing the common law to be developed as no there were no other rules which could give effect to the concerned rights. ${ }^{64}$

In Stransham-Ford, the court could not have developed the common law by introducing a new legal rule. This is because existing rules of criminal law could be adapted so as to give effect to Stransham-Ford's constitutional rights. Such an approach would be in line with the principle that judicial intervention, when it cannot be avoided, should be incremental. ${ }^{65}$ An introduction of a new rule conceivably would mean that PAS and PAE are regulated outside the scope of criminal law as we know it. This would constitute an unnatural and illogical development of the common law, which is outside its own dogmatic framework. No court may do this. Furthermore, developing the common law in this instance by introducing a new rule usurps the constitutionally mandated power of the legislature, since the development is beyond what is required to give effect to the rights at issue.

\section{Significantly changing an existing rule}

Superior courts have constitutionally authorised power to change longstanding principles of the common law through section 173 of the Constitution. The power is conferred on them because they are the

$61 \quad H v$ Fetal Assessment Centre 20152 SA 193 (CC).

62 Loggerenberg "The Tenability of the Constitutional Court's arguments in Support of the Possible Recognition of Wrongful-life Claims in South Africa" 2017 South African Law Journal 163.

63 Friedman v Glicksman 19961 SA 1134 (W) 1138A.

$64 \mathrm{Hv}$ Fetal Assessment Centre supra, (CC) 200F-201 A. The court also reasoned that where a rule is changed altogether, it would have been capable of deciding the development of the common law on exception. However, it decided that the case involved an introduction of a new rule, and it is better for the High Court to make a final decision after hearing all the evidence and considering all the relevant factors. Jabavu et al confirm this by saying that "if the High Court follows the Constitutional Court's lead and recognises the new course of action, it will amount to the introduction of a new legal rule." See Jabavu, Linscott, Mukheibir The Law of Delict in South Africa (2018) 60.

65 Du Plessis v De Klerk 19963 SA 850 (CC) 886D. 
"protectors and expounders of the common law". ${ }^{66}$ A court may do so in order to give better effect to the rights in the Bill of Rights. ${ }^{67}$

In Du Plessis $v$ Road Accident Fund, ${ }^{68}$ Du Plessis sought damages from the Road Accident Fund for loss of support due to the death of his longterm partner resulting from a motor vehicle collision. In response, the Road Accident Fund argued that the claim was not maintainable in law. ${ }^{69}$ The court had to determine whether the common law action for compensation for loss of support should be developed to include persons in same-sex relationships. The court re-alliterated the growing position of the legislature and the courts to confer greater rights on persons such as Du Plessis and found that Du Plessis's right to support was worthy of protection. To afford such protection the court changed the common law in relation to who can claim for loss of support to include persons in a same-sex permanent relationship. In a unanimous decision, Cloete JA, held:

"First, the extension is in line with the common-law principles formulated in Henery (supra) and Amod (supra). Second, the extension is in accordance with the behest of the Constitution."70

And:

“... the plaintiff, as a same-sex partner of the deceased in a permanent life relationship similar in other respects to marriage, in which the deceased had undertaken a contractual duty of support to him, is entitled to claim damages from the defendant for loss of that support."71

In respect to principles of criminal law, a physician or any person who engages in assisted suicide will be guilty of murder. They are guilty because they intentionally and unlawfully caused the patient's death. Significantly changing this common law rule would mean that the definition of murder is amended so as to limit the scope of liability for physicians who act at the behest of patients. However, the High Court in the case of Stransham-Ford would have been precluded from significantly changing an existing rule of common law by replacing an existing definition of the crime of murder because:

"There should if possible be a high rigidity in the definition of crimes; the more precise the definition the better ... it is not for the Courts to create new crimes; nor is it for the Courts to give an extended definition to a crime in order to provide a new protection for property [or person], even if modern

66 Cheadle, Davis and Haysom "The development of all law under the shadow of the foundational principle" in Cheadle, Davis and Haysom South African Constitutional Law: The Bill of Rights (2004) 33-11.

67 Currie and De Waal Chapter 3-61.

68 Du Plessis v Road Accident Fund 20041 SA 359 (SCA).

69 Du Plessis v Road Accident Fund supra, 369A.

70 Du Plessis v Road Accident Fund supra, 376C-D

71 Du Plessis $v$ Road Accident Fund supra, 378B. 
conditions indicate that in some instances such protection might be desirable [author's own emphasis]. ${ }^{72}$

Courts are precluded from doing so by the principle of legality which, inter alia requires that definitions of common law crimes be reasonably precise and settled. ${ }^{73}$ It must be observed that this principle does not prohibit the courts from adjusting the way in which rules are applied in order to meet changed social conditions. ${ }^{74}$ In the words of Lord Dilhorne, "To say that there is now no power in judges to declare new offences does not, of course, mean that well-established principles are not to be applied to new facts."75

Furthermore, it would be undesirable for the court to extend or restrict the definition of the crime of murder as there is no lacuna in the law. The scope of criminal liability for a person engaged in PAS and PAE can be dealt with in terms of existing principles of criminal law.

\section{Adjusting the way an existing rule is applied}

What may be needed in circumstances of a particular case is an adjustment of the way in which long-standing common law principles are applied. $^{76}$ This method of developing the common law was first applied in Minister of Safety and Security $v$ Van Duivenboden ${ }^{77}$ and was later echoed in Carmichele $v$ Minister of Safety and Security ${ }^{78}$ and further cases relating to negligent omissions. Without traversing on well establish facts of Carmichele, the issue was whether the failure by the prosecutor and the investigating officer to oppose bail was wrongful. The High Court and the Supreme Court of Appeal had decided that no legal duty rested on the prosecutor and the investigating officer to prevent harm to Carimichele by opposing bail. In reaching the conclusion, the High Court and the SCA had established that the criteria for determining whether a legal duty existed depended on a proportionality exercise - that is the balancing of the conflicting interests of the parties and the community in accordance with what is considers to be society's notions of what justice demands. ${ }^{79}$

The Constitutional Court however noted that the High Court and the SCA had erred in their decision by assuming that the proportionality exercise was still appropriate in the determination of wrongful omissions. Writing in a unanimous decision, Ackermann and Goldstone JJ held:

$72 \quad R v$ Sibiya 19554 SA 247 (A) 256G-257A.

73 Burchell Principles of Criminal Law (2016) 35.

74 Ramosa "The limits of judicial law-making in the development of commonlaw crimes: Revisiting the Masiya decisions" 2009 SACJ 359-360.

75 Director of Public Prosecution v Withers [1975] A.C 842 at 859.

76 Brand "Influence of the Constitution on the Law of Delict" 2014 Advocate 43.

77 Minister of Safety and Security $v$ Van Duivenboden 20026 SA 431 (SCA).

78 Carmichele $v$ Minister of Safety and Security 20043 SA 431 (SCA).

79 Carmichele $v$ Minister of Safety and Security 20011 SA 489 (SCA) 494F. 
"However, both Courts assumed that the pre-constitutional test for determining the wrongfulness of omissions in delictual actions of this kind should be applied. In our respectful opinion they overlooked the demands of $\mathrm{s}$ 39(2)." 80

This passage shows that the Constitutional Court had considered that the High Court and the SCA had overlooked the demands of the Constitution and that the common law had to be developed beyond existing precedent. What had been required in the determination of whether a legal duty existed was an adjustment of the application of traditional factors - that is the weighing and balancing of the interest of the parties and the community against a consideration of society's notion of justice. The Constitutional Court further held that this proportionality exercise, owing to the establishment of a constitutional state, must now be infused with the values of dignity, equality and freedom. 81

As stated previously, PAS and PAE will constitute the crime of murder if it is proved that in the circumstances there was an intentional and unlawful causing of death of another person. This definition of murder is not unconstitutional to the extent that it criminalises behaviour which is socially and morally reprehensible. Invalidating the definition of murder because it is over-inclusive or under-inclusive is, in the words of Nkabinde J, "to throw the baby with the bath water". ${ }^{82}$ What may be required in the instance is an adaptation of conceptual principles which underlie the existing definition to cover new factual situations.

The court in Stransham-Ford could have considered whether the principle that consent is not a defence to criminal responsibility to a charge of murder should be changed. In developing the common law in this manner the court would have to define the scope and ambit of the requisite departure from or exception to existing principles. It could be argued that the law in relation to the principles of consent should be developed in such a way as to re-enforce the dignity and protection of terminally ill patients before the law and to uphold the rights of these patients and the values in the Constitution. This would be in keeping with the principle of Carmichele, which is when determining wrongfulness, the court must balance the interest of patients, the state and the community in accordance with the objective value system embodied in the Constitution. Thus, in a constitutional democracy, pervaded by the spirit of ubuntu and the values of compassion and human dignity, public policy recognises as being lawful, the agreement by a physician and a terminally ill patient to inflict harm to the latter so as to end suffering and bring about a quick, painless and dignified death.

80 Carmichele $v$ Minister of Safety and Security supra, 955B-C.

81 Carmichele $v$ Minister of Safety and Security supra, 957B-C.

82 Masiya $v$ Director of Public Prosecutions 20075 SA 30 (CC) 45D 


\section{Conclusion}

This paper examined the missteps arising from the High Court decision in Stransham-Ford. In particular, it assessed the manner in which the court sought to develop the common law crime of murder in relation to PAE and PAS. By way of introduction and background the research analysed the available avenues for persons whose death draws near and who may wish to end their intractable suffering. Although lawful, it has been demonstrated that these avenues are of little respite as they do not provide an assurance that the dying process will be quick, painless and dignified. In some instances, these avenues may even lead to protracted suffering.

This paper highlights that this is what prompted Stransham-Ford to approach the North Gauteng High Court for an order that would in effect develop the common law so that assisted suicide and assisted euthanasia become lawful. The High Court accepted that the common law requires development so as to give effect to Stransham-Ford's constitutional rights. However, the manner in which it does this has been shown to be erroneous. The court was too ready to assume that the approach in Carter, a foreign court, can readily be transplanted into our legal system. In doing so, the court overlooked the demands of section 39(2) read with section 173 of the Constitution.

Once the court had determined that the common law is inconsistent with the Constitution in so far as it prohibits PAE and PAE, it concluded that to remedy the situation, just as occurred in Carter, there must be notional severance of the impugned law. This paper in turn argued that notional severance is a device that is available under section 172(1)(b) of the Constitution and which empowers a court to sever unconstitutional provisions from a statute. In Carter, the Supreme Court of Canada had been dealing with provisions of a statute and hence was able to use notional severance, whereas in Stransham-Ford, the High Court was dealing with common law rules. It is section 173 read with section 39(2) of the Constitution that empowers superior courts to develop the common law - taking into account the interests of justice.

The jurisprudence suggests that there are three ways in which common law rules may be developed. A court may introduce a new rule, significantly change an existing rule or adjust the manner in which longstanding principles are applied. After critically analysing the different approaches, it became clear that the most appropriate remedy in the circumstances would have been to adjust the manner in which principles of criminal law in relation to PAE and PAS are applied. The court in Stransham-Ford could have considered whether the principle that consent is not a defence to criminal responsibility to a charge of murder, should be changed. In developing the common law in this manner, the court would have to define the scope and ambit of the requisite departure from, or exception, to existing principles. 